\title{
Study on the Practice of Promoting Overseas Employment by Bilingual Teaching of Three-year College Culinary Majors under the Background of the "Belt and Road"
}

\author{
Hailing Xie \\ Jiangsu College of Tourism, Yangzhou, Jiangsu, 225000
}

Keywords: Culinary Major, Vocation Education, one belt and one road

\begin{abstract}
The culinary profession is one of the specialties in higher education in China. It mainly studies the rules and methods of making Eastern and Western food culture and its dishes. With the acceleration of China's internationalization and modernization process, it is urgent to cultivate high-quality export-oriented culinary senior management talents with high quality theory and practice in the 21st century. Therefore, it is particularly important to use bilingual teaching in some courses of culinary specialty.
\end{abstract}

\section{Introduction}

Bilingual teaching is translated from the English term Bilingual teaching, that is, the teaching of some or all non-linguistic subjects in non-native languages, the actual content of which varies from country to country. For example, in the United States, bilingual teaching generally refers to the teaching of subjects in Spanish; in Canada, bilingual teaching generally refers to the use of French-speaking teaching in English-speaking areas, the purpose of which is to make these bilingual or multilingual countries with many immigrants more It is a good reflection of its diversified communion. In China, bilingual teaching originally referred to schools in ethnic minority areas in order to enable minority students to learn Chinese mainstream language and preserve their minority language teaching activities. However, in recent years, with China's accession to the WTO and economic globalization, English as an international language is particularly important in people's work and life. Moreover, the foreign language courses for Chinese and foreign language majors in Chinese universities are mostly English. Under such circumstances, the basic connotation of bilingual teaching refers to the use of English original textbooks to explain knowledge and impart skills in correctly fluent English. Teaching activities. Of course, in order to avoid students' thinking obstacles due to language lag in the teaching process, Chinese is not absolutely excluded. In this bilingual teaching, English is only the language and means of teaching, not teaching subjects.

\section{The importance of bilingual education in the cooking profession}

With China's accession to the WTO and the further deepening of reform and opening up, international exchanges between various industries have increased. For example, Yangzhou University's Tourism Culinary Institute has been a good cooperative relationship with foreign counterparts since it first established culinary higher education in the country in 1983, such as similar institutions with Japan, Canada, Australia, France, New Zealand and other countries. Conduct academic cooperation and exchange visiting scholars or international students. The college has received hundreds of academic visits, visits and trainings in more than 20 countries and regions. With the further deepening of international exchanges, the society needs a large number of bilingual professionals. On the other hand, from the perspective of the future development of students, only qualified bilingual professionals can have an advantage in the future competition. Proficiency in bilingualism has become a future development of students. Important conditions.

In 2001, the Ministry of Education promulgated the No. 4 document on strengthening the undergraduate teaching work of higher education schools to improve the quality of teaching. It 
proposed that all colleges and universities across the country strive to open $5 \%$ to $10 \%$ of bilingual courses within 2 3 years. Therefore, universities around the country have started bilingual teaching, and strive to cultivate high-quality compound talents to meet the needs of economic globalization and improve students' practical application ability in foreign languages. Bilingual teaching in cooking is also the first to explore in this situation.

Culinary major is one of the specialties in higher education in China. It mainly studies the rules and methods of making Eastern and Western food culture and its dishes, and also shoulders the important task of spreading food culture. In order to cultivate high-quality senior management talents who have a good understanding of the Eastern and Western food culture and have certain operational skills, and to strengthen the construction of specialties, it is particularly important to use bilingual teaching in some courses of culinary specialty. For example, the Western Cuisine Course is an important professional course established in China's culinary higher education majors. It mainly studies the rules and methods of making Western food culture and its dishes. Western countries are customarily referring to European countries and regions, as well as the vast regions of North America, South America and Oceania where these countries and regions are the main immigrants. The language involved is mostly English. In order to study Western food culture in depth, to understand its customs, eating habits, mastering professional English and using bilingual teaching is an important way. Similarly, through bilingual teaching, we can also introduce our country's long and splendid food culture, exquisite and numerous methods of making dishes to the world.

\section{Feasibility of implementing bilingual teaching in culinary profession}

The practice of bilingual education in the cooking profession must first improve the English level of students. Take the Yangzhou University Tourism Culinary Institute as an example. After the students enter the school, in addition to the college English courses, the college also offers a restaurant English conversation course to improve the students' oral English. In addition, the Student Union and the Youth League Committee regularly conduct oral English training, set up a small English corner, organize English speech contests, English song singing contests and other activities. The college's speech room is open 24 hours a day, which greatly enriches students' spare time and helps to improve. The English level of the students. Some classes use English to publish blackboards to create an atmosphere in which students learn English. Some classmates, the higher pass rate of English four, created conditions for bilingual teaching. During the bilingual teaching of individual classes in the third and fourth grades, the students basically adapted to bilingual teaching. In the classroom, teachers and students interacted with each other and achieved good teaching results.

Secondly, the cooking profession must have qualified teachers to implement bilingual teaching. As we all know, bilingual teachers undertake a dual task, which not only teaches the professional content of the subject, but also fluently and accurately expresses the teaching content in English. Therefore, as a bilingual teacher, it is necessary not only to be proficient in the subject content, but also to be a bilingual. At present, the Yangzhou University Tourism Culinary Institute and other institutions have regular or irregular academic exchanges with foreign countries, which brings opportunities for teachers to study or study abroad, which helps to improve teachers' English and professional standards. At the same time, many professional teachers continuously improve their English level through self-study and reference to the original textbook teaching. Therefore, the Yangzhou University Tourism Culinary Institute has a certain teacher base for the implementation of cooking bilingual teaching in some courses.

Third, the development of bilingual education in cooking should have appropriate textbooks. From the current situation, bilingual textbooks are divided into foreign introduction textbooks, domestic publishing textbooks, school self-editing textbooks and translation textbooks. In the choice of teaching materials, it should be determined according to the specific circumstances, involving Western food, nutrition, health, chemistry, etc., should choose the original textbook, for example: Yangzhou University Tourism Culinary Academy's Western course chose Jams Peterson's 
Essentials of Cooking ( The publication week in the United States is called extraordinary, and the New York Times is known as a very detailed book. The teaching effect is as good as the book says: not only know how to do it, but You should know why). For Chinese courses such as Chinese food, it is advisable to choose translation materials and translate the mother tongue into English textbooks. This will not only systematically teach Chinese long-standing food culture and food production, meet the needs of students for professional knowledge, but also meet the requirements of teaching and improve students. Professional English level. In addition, in order to expand the knowledge of students, a certain number of original teaching reference books provided by the library can also be used.

\section{Culinary professional bilingual teaching curriculum design}

Culinary higher education courses are usually divided into public courses, professional basic courses, professional courses and elective courses. Which courses do you choose to implement bilingual teaching? According to the current situation of the culinary profession, choose some Western food crafts as mentioned above. In the professional basic course, "Culinary Nutrition", "Cooking Hygiene", "Cooking Chemistry", "Cooking Microbiology", "Computer", "Chinese Famous Cuisine Names" in the professional course, etc., implement bilingual teaching. Because the expressions, meanings, and technical terms of these courses are consistent in understanding and interpretation in bilingual, it is suitable for bilingual teaching, which is convenient for students to master theoretical knowledge and improve their practical ability. As for the local and national cultures in the humanities disciplines involved in the professional courses in the teaching plan, such as "Introduction to Chinese Cooking", "Chinese Cooking History", "Chinese Pastry History" and other courses, it is more difficult to teach in English. Do not implement bilingual teaching. The formulation and selection of textbooks should be analyzed on a case-by-case basis and explained above.

The teaching method is to complete a certain teaching task. The teaching and learning behaviors jointly adopted by teachers and students include both the methods of teaching teachers and the methods of student learning. They are the unity of teaching methods and learning methods. At present, the effective methods accumulated in teaching practice are too numerous to enumerate. According to incomplete statistics, there are more than 700 kinds. However, it is often said that "teaching has a law, teaching has no law, and you are getting the law." There are many different forms of bilingual teaching. For the culinary profession, not every course is bilingual. It can be one or several qualified courses, and some or all of them use bilingual teaching. Taking "Western Cuisine" as an example, in the early stage of bilingual teaching, English and Chinese can be taught simultaneously, and all of them are taught in English in the later stage. This is a step-by-step process, which mainly depends on the improvement of students' English proficiency. In order to cultivate students' practical ability and realize the dual teaching objectives of bilingual teaching, it is necessary to change the traditional "cramming" teaching method and replace it with the "student-centered" new teaching mode. In the classroom, the emphasis is placed on the interaction between teachers and students, and the role of teaching resources and teaching environment in teaching is emphasized. Over time, unexpected effects will be received. At the same time, teachers should actively use the Internet, electronic reading rooms, multimedia classrooms, etc. to carry out multimedia teaching, broaden students' horizons, increase the image and vividness of the teaching content, and thus stimulate students' interest in learning. In addition, in order to make up for the lack of classroom teaching, give full play to the students' specialties, and cultivate students' hobbies, we can develop a second classroom activity that integrates academic, intellectual, fitness and entertainment according to the characteristics of bilingual teaching, such as knowledge lectures. And activities such as speaking, listening, and skills competitions (including English). This not only enriches the students' spare time, but also improves the students' English level and lays a good foundation for the implementation of bilingual teaching. 


\section{Conclusion}

With the continuous enrichment of the course content and the continuous improvement of the professional course mode, it is hoped that practitioners who have introduced other professional bilingual courses will pay attention to it, so as to carry out further specific research on the bilingual teaching of cooking courses and other professional courses, and do a good cooking class. The implementation of the bilingual curriculum model will improve the attention of students and teachers in secondary vocational colleges to the curriculum, grasp all aspects, focus on the various factors influencing bilingual teaching, pay attention to the improvement of teaching efficiency, and do the best for bilingual teaching. Enthusiasm is not enough. It requires the close cooperation of each school and teachers, so that the bilingual teaching of cooking courses can better study and implement improvement measures.

\section{Acknowledgements}

Project:2018 annual topic of Jiangsu Education Science 13th Five-Year plan: the practice of pro moting overseas employment by bilingual teaching in the three year college cuisine specialty under the background of "one belt and one road". taking Jiangsu College of Tourism as an example, the to pic number is B-b/2018/03/33

\section{References}

[1] Zhou Fengcui Chang on the reform of higher vocational culinary education under the new situation [J]. Journal of Chongqing University of Science and Technology, 2005, (04): 18 -22

[2] Sun Kekui, Wang Haibo, Thoughts on the Teaching Reform of Culinary Higher Education Skills [J]. Journal of Huangshan University, 2004, (02): 87 -89

[3] Sun Hui. Preliminary study on bilingual teaching in higher vocational colleges [J]. Vocational Education Forum, 2003, (10): 1-3

[4] Li Jingrui's bilingual teaching of cooking courses [J]. Journal of Yangzhou University, 2007 